\title{
Comments on the Pteranodontidae (Pterosauria, Pterodactyloidea) with the description of two new species
}

\author{
ALEXANDER W.A. KELLNER \\ Setor de Paleovertebrados, Museu Nacional/UFRJ \\ Quinta da Boa Vista s/n, São Cristóvão, 20940-040 Rio de Janeiro, RJ, Brasil \\ Manuscript received on September 15, 2010; accepted for publication on October 25, 2010
}

\begin{abstract}
Considered one of the best known flying reptiles, Pteranodon has been subject to several reviews in the last century. Found exclusively in the Upper Cretaceous Niobrara Formation and Pierre Shale Group 11 species have been attributed to this genus (excluding the ones presently regarded as representing Nyctosaurus). While reviewers agree that this number is inflated, there is disagreement on how many species can be identified. The last review recognized only two species (Pteranodon longiceps and Pteranodon sternbergi) both being sexually dimorphic. Based on several cranial features, some specimens previously referred to the genus Pteranodon are re-evaluated leading to the recognition of the following species, two of which new that are described here: Pteranodon longiceps, Geosternbergia sternbergi, Geosternbergia maiseyi sp. nov., and Dawndraco kanzai gen. et sp. nov. They differ mainly by features such as the direction and extension of the frontal crest, the angle and extension of the posterior process of the premaxillae, the shape and extension of the lower temporal fenestra and the length and proportion of the rostrum. The procedures to recognize a pterosaur species are also discussed here, and must take into account primarily morphology, in conjunction with stratigraphic and geographic data. Although well aware that changes in morphology not always reflect taxonomy, the lack of stratigraphic data and the limited number of specimens that can be confidently assigned to one species hampers our understanding on the morphological variations as a function of ontogeny, individual variation and sexual dimorphism. Although the present study has not eliminated the possibility to recognize such differences, caution is needed before models are generalized for pterosaurs.
\end{abstract}

Key words: Pterosauria, Pteranodon, Dawndraco, Late Cretaceous, Taxonomy.

\section{INTRODUCTION}

The pterodactyloid Pteranodon can be considered one of the best known flying reptiles. Thousands of specimens from almost complete skeletons to very fragmentary and isolated remains are referred to this genus, which is found exclusively in the Upper Cretaceous Niobrara Formation and Pierre Shale Group (Bennett 1994, Martin et al. 2007). Othniel Charles Marsh (1831-1899) was the first to describe North American pterosaurs in several short papers naming seven species of which Pteranodon longiceps was the first (Marsh 1876a). Unfortunately, in most cases he has not figured the mate-

E-mail: kellner@mn.ufrj.br rial, including the holotypes, which became a source for confusion (e.g., Schoch 1984, Bennett 1994).

After the pioneer work of Marsh, Pteranodon remains have received considerable attention by researchers. The first review was provided by Eaton (1910) who accepted several of the species proposed by Marsh and further referred cranial material to some of them, which has been questioned by subsequent workers (e.g., Schoch 1984). Harksen (1966) introduced Pteranodon sternbergi based on a very large but incomplete skull which was afterward referred to the sub-genus Sternbergia by Miller (1972a). However, since the name was preoccupied, this author replaced Sternbergia for 
Geosternbergia, which was still regarded as a sub-genus of Pteranodon (Miller 1978).

While reviewing the taxonomy of Pteranodon (including some species of Nyctosaurus), Schoch (1984) figured for the first time several type specimens housed at the Yale Peabody Museum and provided some taxonomic suggestions. The last and more comprehensive review of this genus was provided by Bennett (1991, 1994, 2001a, b) who concluded the existence of two species - Pteranodon longiceps and Pteranodon sternbergi, both being sexually dimorphic. All other species were regarded as nomina dubia since they were based on inadequate specimens (see also Miller 1972a).

In 2008 I had the opportunity to examine a partial skeleton deposited in the Geology Museum of the University of Alberta in Edmonton (UALVP 24238) whose skull was briefly illustrated and attributed to Pteranodon sternbergi by Bennett (1994). Another specimen examined by me in 1989 consists of a partial skull deposited in the Natural History Museum of the University of Kansas in Lawrence (KUVP 27821) and was also briefly illustrated by Bennett (1994) who considered it an individual of Pteranodon longiceps. These specimens are here regarded to represent different species prompting a short taxonomic review of what can be called the Pteranodon-complex.

Anatomical abbreviations: ac - acetabulum, cdv caudal vertebrae, d - dentary, dca - distal carpal series, dlca - distal lateral carpal, $\mathrm{f}$ - frontal, fcr - frontal crest, fe - femur, fola - foramen lacrimale, gas - gastralia, il ilium, is - ischium, $\mathrm{j}$ - jugal, j.rid - jugal ridge, 1 - left, la - lacrimal, ltf - lower temporal fenestra, $\mathrm{m}$ - maxilla, mcIV - metacarpal IV, n - nasal, naof - nasoantorbital fenestra, obfo-obturator foramen, or - orbit, $\mathrm{p}$ - parietal, pm - premaxilla, ppu - prepubes, po - postorbital, pu pubis, q - quadrate, qj - quadratojugal, r - right, rapr retroarticular process, sq - squamosal, sri - sternal rib, sv - sacral vertebra, utf - upper temporal fenestra.

\section{SYSTEMATIC PALEONTOLOGY}

Pterosauria Kaup 1834

PterodaCtyloideA Plieninger 1901

DSUNGARIPTEROIDEA Young 1864

ORNITHOCHEIROIDEA Seeley 1870

Pteranodontidae Marsh 1876
Pteranodontia Marsh 1876

PTERANOdONTINAE Williston 1892

ORNITHOSTOMATIDAE Williston 1893

ORNiTHOSTOMATINAE Williston 1897

PTERANODONTES Gadow 1901

Type genus: Pteranodon Marsh 1876

Definition: The last most recent common ancestor of Pteranodon longiceps, Geosternbergia sternbergi, Dawndraco kanzai gen. et. sp. nov., and all its descendants.

Taxa included: Pteranodon longiceps, Geosternbergia sternbergi, Geosternbergia maiseyi sp. nov., and Dawndraco kanzai gen. et. sp. nov.

Recorded temporal and stratigraphic range: Coniacian to Campanian; Smoky Hill Chalk Member of the Niobrara Formation (Coniacian to Early Campanian) to the Sharon Springs Formation (Campanian) of the Pierre Shale Group (Bennett 1994, Martin et al. 2007).

Synapomorphies: Large frontal crest forming the main part of the cranial crest; premaxilla with a posterior process that makes the lower anterior margin of the cranial crest; raised margins of the jaws composed of dense bone for at least the proximal half of the jaws; mandibular symphysis reaching more than half the total length of the mandible; toothless jaws (condition also present in other clades).

Remarks: Based on the first skull of a North American pterosaur Marsh (1876a) named Pteranodon longiceps and recognized that it belonged to a distinct group of flying reptiles. In the same paper, this author established the new order (in the Linnean sense) Pteranodontia (although in the title of the article he mentioned suborder) and, within this order, the family Pteranodontidae. Williston (1892) considered this group as a subfamily (Pteranodontinae) and later (Williston 1893) regarded Pteranodon as a junior synonym of Ornithostoma which was introduced by Seeley (1871) based on a toothless jaw from the Cambridge Greensand. Therefore Williston (1893) replaced Pteranodontidae for Ornithostomatidae (and later for Ornithostomatinae - Williston 1897). However, it is highly unlikely that Pteranodon was present in the Cambridge Greensand judging from the present known distribution of this taxon. Furthermore, this association is hard to prove at best, based on 
the fact that fragments of toothless pterosaurs of distinct groups are difficult to tell apart. Most reviewers accept Pteranodon as a valid genus (e.g., Eaton 1910, Miller 1972a, Schoch 1984, Wellnhofer 1978, Bennett 1994), separated from Ornithostoma (a taxonomic problem on its own).

Marsh (1876b) considered Nyctosaurus to be part of the Pteranodontidae, which was followed by some authors who reviewed the pterosaur material from the Late Cretaceous of Kansas (e.g., Miller 1972a, Wellnhofer 1978, Schoch 1984). Williston (1903) separated Nyctosaurus in the Nyctosaurinae, a group apparently introduced previously by Nicholson and Lydekker (Averianov 2006). Nowadays most authors consider Nyctosaurus to be part of the clade Nyctosauridae (e.g., Bennett 1989, Wellnhofer 1991, Kellner 2003, Frey et al. 2006). Bennett $(1989,1994)$ regarded several toothed taxa as part of the Pteranodontidae that are presently separated in distinct clades such as the Anhangueridae and the Istiodactylidae (e.g., Howse et al. 2001, Kellner 2003, Wang et al. 2005).

Since the relationships of Pteranodon, Geosternbergia, and Dawndraco are not yet clear, a broader node-based definition of the Pteranodontidae including all type species of the three genera is adopted here.

\section{Pteranodon Marsh 1876}

\section{Longicepia Miller 1972}

Type species: Pteranodon longiceps Marsh 1876

Taxa included: Limited to the type species; other species (or specimens) originally regarded as belonging to Pteranodon are nomina dubia or classified in another genus (see Miller 1972a, Schoch 1984, Bennett 1994).

Recorded temporal and stratigraphic range: Late Santonian-Early Campanian (Late Cretaceous); upper part of the Smoky Hill Chalk Member of the Niobrara Formation (Bennett 1994).

Diagnosis: As for the type species.

Remarks: The genus Pteranodon was introduced by Marsh (1876a) with Pteranodon longiceps as the type species of the genus. In the same paper, he introduced the species Pteranodon comptus and transferred the previously described Pterodactylus oweni, Pterodactylus ingens, and Pterodactylus velox to Pteranodon. Except for a reconstruction presented by Marsh (1884) of Pteranodon longiceps, none of the specimens were illustrated and no type specimen was clearly designated.

Later, Williston (1893) regarded Pteranodon as junior synonym of Ornithostoma but, as pointed out before, it is highly unlikely that the toothless pterosaurs from the Cambridge Greensand and the Cretaceous deposits of the Niobrara (and Sharon Spring) Formation are congeneric.

In what can be regarded as the first comprehensive review of Pteranodon, Eaton (1910) provided the description and illustration of several new Pteranodon specimens, including the type of Pteranodon longiceps (YPM 1177, see below). This author also assigned, rather arbitrarily, some cranial remains to previously described species but did not establish major taxonomical changes.

Many decades later, Miller (1972a, b, 1973, 1978) reviewed part of the Pteranodon material and introduced several sub-genera that has generated some controversy (e.g., Wellnhofer 1978, Schoch 1984, Bennett 1994). Miller was also the first to regard the species Pterodactylus oweni (= Pterodactylus occidentalis), Pterodactylus ingens, Pterodactylus velox, Ornithochirus umbrosos, Ornithochirus harpyia, and Pteranodon comptus as nomina dubia, which was followed by Bennett (1994) and is accepted here. Miller (1972a) regarded Nyctosaurus as a sub-genus of Pteranodon, which is refuted by several authors (e.g., Wellnhofer 1978, Bennett 1994, Kellner 2003, Unwin 2003).

A very important contribution to the Pteranodon (and Nyctosaurus) study was done by Schoch (1984), who provided the first illustrations of previously described species and the designation of several lectotypes.

The last and more comprehensive review of Pteranodon was made by S.C. Bennett, both in terms of taxonomy (Bennett 1994) and osteology (Bennett 1991, 2001a, b). Except for the material attributed to Nyctosaurus, this author considered the pterosaur material from the Smoky Hill Chalk and the overlying Sharon Springs Formation as belonging to two distinct species of Pteranodon (Pteranodon longiceps and Pteranodon sternbergi - the latter described by Harksen 1966), which, according to him, were also sexually dimorphic (Bennett 1992). However, several cranial morphologi- 
cal features suggest that the diversity within the Pteranodon-complex is higher than previously regarded. Here the genus Pteranodon is restricted to the type species (Pteranodon longiceps) and Geosternbergia is revalidated for "Pteranodon" sternbergi as suggested before (Miller 1972a, 1978).

Eaton (1910) and Bennett $(1991,1994)$ pointed out that the postcranial bones of Pteranodon have not proven to be diagnostic at a species level. Bennett (1994) relied essentially on stratigraphic data to associate postcranial elements to one of the two Pteranodon taxa that he recognized. Since most of the pterosaur material reviewed by him lacks detailed stratigraphic information, he identified them only as Pteranodon sp. This did not include the specimens that were recognized as pertaining to Nyctosaurus, which were not the main target of his review (Bennett 1994).

Examining both the literature and original postcranial specimens, there are some variations in anatomy (e.g., proportions of bones, expansion of articulations, orientation of tubercles and processes) that may express true anatomical differences (and not taphonomic artifacts) and might turn out to be useful taxonomically. Unfortunately, the majority of the pteranodontid material is represented by incomplete skeletons and only a few show preserved skulls that allow the identification at the species level. Until detailed comparisons among the postcranial bones of these few specimens are made (e.g., UALVP 24238, YPM 2473), the distinction of Pteranodon and closely related taxa (Geosternbergia and Dawndraco) will have to rely mostly on cranial features (see respective diagnosis).

Among the diagnostic features of Pteranodon, Bennett (1994) pointed out the presence of a premaxillary crest. However, none of the specimens that I have examined shows evidences of such a structure. Several of Bennett's Pteranodon characters are here regarded to diagnose a more inclusive taxon - the Pteranodontidae, which is restricted to Pteranodon, Geosternbergia and Dawndraco.

\section{Pteranodon longiceps Marsh 1876}

Pteranodon (Longicepia) longiceps Marsh: Miller 1972 Pteranodon (Longicepia) marshi Miller 1972

Pteranodon (Pteranodon) longiceps Marsh: Miller 1973
Pteranodon (Pteranodon) marshi Miller: Miller 1973

Pteranodon (Sternbergia) walkeri Miller 1972

Pteranodon (Geosternbergia) walkeri Miller 1973

Holotype: Almost complete skull (lacking part of the cranial crest), partial radius, proximal end of the second wing phalanx and other fragments housed at Peabody Museum of Natural History of the Yale University, New Haven, Connecticut, United States of America (YPM 1177 , cast MN 6953-V).

Occurrence: The holotype was collected near the Smoky Hill River, Gove County, Kansas (see Bennett 1994).

Recorded temporal and stratigraphic range: Late Santonian-Early Campanian (Late Cretaceous); upper part of the Smoky Hill Chalk Member of the Niobrara Formation (Bennett 1994).

Diagnosis: Large and elongated frontal crest directed posteriorly; premaxillary process forming the anterior margin of the cranial crest reaching the region above the orbit; posterior premaxillary process inclined for about $25-30^{\circ}$ relative to the ventral margin of the skull; dorsal margin of the skull anterior to the orbit almost straight; jaws tapering distally to points (also potentially present in Geosternbergia); mandibular symphysis reaching about two thirds of the total length of the mandible; knob-like nasal process; presence of a nutrient foramen on the dorsal surface of the proximal half of the humerus.

Remarks: In his review, Bennett (1994) considered several cranial remains as part of Pteranodon longiceps and almost all postcranials associated to this species were based on stratigraphy. Besides the well-preserved holotype (YPM 1177, cast MN 6953-V), the most significant specimen of this species is FHSM VP 2183 (originally SMM 11402), first described by Miller (1972b). Pictures of this specimen shows the presence of a nutrient foramen on the dorsal side of the humerus, which Bennett (1994) observed in other humeri attributed to Pteranodon (not identified at a species level) and is therefore regarded as diagnostic for Pteranodon longiceps. However, it cannot be assured at this time that this feature is also not present in Geosternbergia, to which no postcranial bone can be associated with confidence, or in Dawndraco kanzai gen. et. sp. nov., which has the dorsal side of the humeri embedded in the matrix. 
Bennett (1994) included in the diagnosis of Pteranodon that the premaxillae extended beyond the tip of the mandible, but the holotype of Pteranodon longiceps which is complete, does not show that (Marsh 1884, Eaton 1903, 1910; see also remarks in Geosternbergia and Dawndraco).

Eaton (1910) designed YPM 2594 as belonging to "Pteranodon ingens" and YPM 2473 as Pteranodon sp. In his review, Miller (1972a) regarded YPM 2594 as the holotype of a new species, Pteranodon (Longicepia) marshi, and YPM 2473 as representing Pteranodon longiceps. Both specimens were considered by Bennett (1994) as Pteranodon longiceps. Although the holotype of Pteranodon longiceps (YPM 1177) shows an incomplete cranial crest, particularly at the posterior margin, there is no marked anatomical difference between the comparable parts of YPM 1177 and YPM 2594 , including the inclination of the quadrate. Therefore, both specimens can be regarded as representing the same species (as indicated by Schoch 1984), and Pteranodon marshi should be considered as objective junior synonym of Pteranodon longiceps, as established by Bennett (1994). The second specimen, YPM 2473 (cast MN 6954-V), is very incomplete and consists mainly of the braincase and the cranial crest. The elongated crest of YPM 2473 differs from the crest of YPM 2594 mainly by being more vertical (Bennett 1994), less expanded dorso-ventrally and having the antero-dorsal margin in lateral view rather straight and not concave. Due to the incompleteness of YPM 2473, which also appears to have the bony portion above the orbit more developed than in Pteranodon longiceps (YPM 1177, YPM 2594, and FHSM VP 2183), this specimen is here regarded as Pteranodon sp. following Eaton (1910).

Miller (1972a) further erected the species Pteranodon (Sternbergia) walkeri based on FHSM VP 221 (former SMM 2851). Bennett (1994) argued that the reconstruction of this specimen done by Miller was wrong, pointing out (among other reasons) that the margins of the crest are not preserved and that there are no evidences of the crest in FHSM VP 221 to be upright (as in Geosternbergia). He concluded that Pteranodon walkeri was a junior synonym of Pteranodon longiceps, which is followed here.
In his review, Bennett (1994: 30) regarded the skull KUVP 27821 from the Sharon Springs Formation (Lower Campanian, Martin et al. 2007) as representing Pteranodon longiceps, but several cranial features suggest that this species cannot be classified in this species and is here regarded as Geosternbergia (see Geosternbergia maiseyi $\mathrm{sp}$. nov.). Therefore it is not certain if Pteranodon longiceps is present in the Sharon Springs Formation.

\section{Genus Geosternbergia Miller 1978}

Sternbergia Miller 1972 non Paula Couto 1970, non Jordan 1925

Type species: Geosternbergia sternbergi (Harksen 1966).

Taxa included: Geosternbergia sternbergi and Geosternbergia maiseyi sp. nov.

Recorded temporal and stratigraphic range: Late Coniacian-Campanian (Late Cretaceous); lower part of the Smoky Hill Chalk Member of the Niobrara Formation (late Coniacian to early Santonian) and Sharon Springs Formation (Campanian) of the Pierre Shale Group (Bennett 1994, Martin et al. 2007).

Diagnosis: Large and upward-directed frontal crest; frontal crest bulbous in profile; premaxillary process forming the anterior margin of the cranial crest ending before or at the region corresponding to the anterior margin of the orbit; posterior premaxillary process inclined for more than $40^{\circ}$ relative to the ventral margin of the skull; lower temporal opening broader and more oval than in Pteranodon and Dawndraco.

Remarks: Harksen (1966) described a skull with a large crest as Pteranodon sternbergi, which was regarded by Miller (1972a) to represent a new sub-genus named by him Sternbergia. However, this name was preoccupied (by two taxa) and Miller (1978) replaced it for the sub-genus Geosternbergia. Wellnhofer (1978) considered Sternbergia (consequently also Geosternbergia, published in the same year) synonymous with Pteranodon, what was followed by Bennett (1994).

The present review agrees with Miller (1972a, 1978) in separating Geosternbergia and Pteranodon at the genus level, which is based on the several distinct cranial features discussed above. 
Geosternbergia sternbergi (Harksen, 1966)

Pteranodon sternbergi Harksen 1966

Pteranodon (Sternbergia) sternbergi Miller 1972

Pteranodon (Geosternbergia) sternbergi Miller 1978

Holotype: Incomplete skull lacking most of the anterior end and fragmentary lower jaw housed at Fort Hays State Museum (former Sternberg Memorial Museum SMM), Fort Hays State University, Hays, Kansas, United States of America (FHSM VP 339, former SMM 5426).

Occurrence: The holotype (FHSM VP 339) was collected in the Graham County, Kansas (see Bennett 1994 for details).

Recorded temporal and stratigraphic range: Late Coniacian to early Santonian (Late Cretaceous); lower part of the Smoky Hill Chalk Member of the Niobrara Formation (Bennett 1994).

Diagnosis: Upward-directed frontal crest much larger than that of Geosternbergia maiseyi tripling the height of the skull; premaxillary process forming the anterior margin of the cranial crest very long; posterior premaxillary process sub-vertical; premaxillary process forming the anterior margin of the cranial crest ending well before the orbit (in lateral view); dorsal margin of the skull anterior to the orbit concave (in lateral view).

Remarks: The holotype of Geosternbergia sternbergi represents one of the largest flying reptiles recovered from the Niobrara Formation, known solely from one skull. Bennett (1994) reviewed this specimen in detail, indicating that several parts of the bone are covered by plaster, with very little of the lower jaw preserved. Nonetheless, the skull and mandible are in their correct anatomical position and the concave dorsal margin of the skull appears to be correct. Bennett (1994) also regarded that the "high crested pterosaurs" from the Niobrara Formation as having jaws that appear to taper distally, similar to Pteranodon. Although the holotype of Geosternbergia sternbergi lacks the distal ends of the jaws, the preserved portions of the upper jaw do indeed taper distally, confirming Bennett's observation.

Geosternbergia maiseyi sp. nov.

Pteranodon longiceps Bennett 1992
Etymology: The specific name honors Dr. John G. Maisey, a researcher at the American Museum of Natural History (AMNH, New York) for his contribution to vertebrate paleontology.

Holotype: Posterior part of the skull housed at the Natural History Museum, University of Kansas, Lawrence, Kansas, United States of America (KUVP 27821, Fig. 1).

Occurrence: The holotype comes from the Edgemont area of South Dakota, USA. Other pterosaur postcranial elements have been collected in this and other regions, but cannot confidently be assigned to Geosternbergia maiseyi at the time being (e.g., Hargrave 2007).

Recorded temporal and stratigraphic range: Campanian (Late Cretaceous); Sharon Springs Formation of the Pierre Shale Group (Bennett 1994, Martin et al. 2007).

Diagnosis: Upward-directed frontal crest that doubles the height of the skull (lower than in Geosternbergia sternbergi); posterior premaxillary process inclined for about $55^{\circ}$ relative to the ventral margin of the skull, smaller than in Geosternbergia sternbergi; premaxillary process forming the anterior margin of the cranial crest ending at the region corresponding to the anterior margin of the orbit (in lateral view); dorsal margin of the nasoantorbital fenestra straight, suggesting a comparatively larger opening than in other pteranodontids; main axis of orbit sub-vertical; ventral margin of the jugal more concave (in lateral view) than in other pteranodontids.

Short description: The holotype of Geosternbergia maiseyi (KUVP 27821) consists of a partial skull exposed in right lateral view, lacking the anterior part. The specimen is compacted and the elements are rather brittle, with the bone surface not very well preserved, contrasting with most of the pteranodontid specimens from the Niobrara Formation. The preserved portion of the nasoantorbital fenestra has a straight dorsal margin, suggesting that this opening was proportionally larger than in Pteranodon, Dawndraco and also Geosternbergia sternbergi. The orbit is pear-shaped, with the main axis sub-vertical relative to the ventral margin of the skull. Lower temporal fenestra is well preserved and larger than in Pteranodon and Dawndraco, which is also seems to be the case for Geosternbergia sternbergi. 

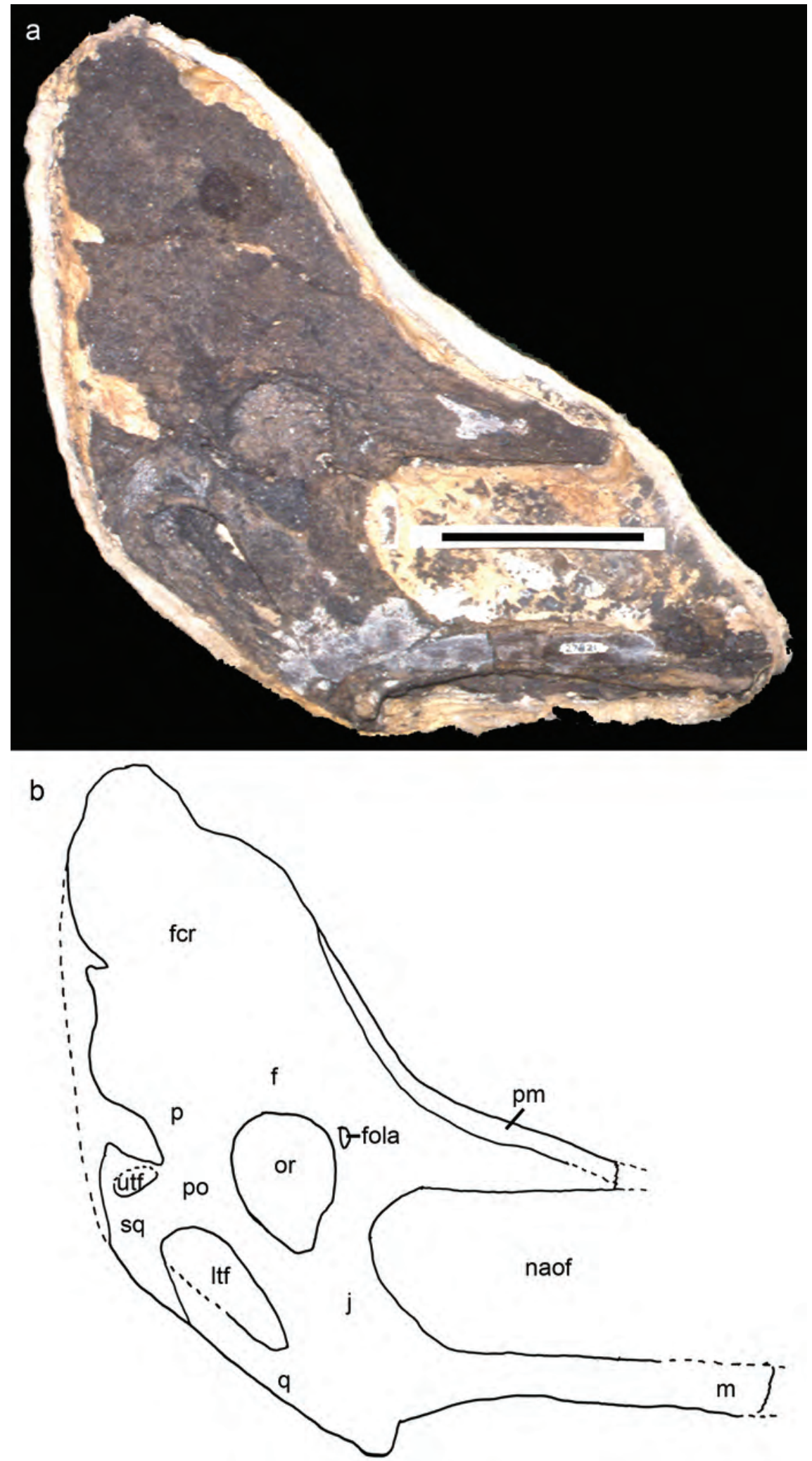

Fig. 1 - Geosternbergia maiseyi sp. nov., holotype (KUVP 27821). (a) photograph and (b) sketch of the skull. Scale bar: $100 \mathrm{~mm}$. 
The most conspicuous feature of Geosternbergia maiseyi is the large cranial crest composed essentially of the frontal. It is upward-directed, but not as much as in Geosternbergia sternbergi. The premaxillary process that forms the anterior margin of the crest is more inclined than in Pteranodon and Dawndraco but less than in Geosternbergia sternbergi. Due to this inclination, the premaxillary process reaches the region that corresponds to the anterior margin of the orbit, contrary to the condition observed in Geosternbergia sternbergi, where this process is sub-vertical and much longer.

Remarks: Bennett $(1991,1992)$ published a line drawing of KUVP 27821 (repeated in subsequent publications - Bennett 1994, 2001a), which he considered to be a large male of Pteranodon longiceps. He also used the occurrence of KUVP 27821 to extend the range of this species to the Sharon Springs Formation (Bennett 1994).

During my examination of this specimen (in 1989, before Bennett's publication) several differences between Pteranodon cranial material described by Eaton (1910) and Miller (1972a, b) were noted (see diagnosis and short description). Among these differences is the large upward projected crest that contradicts the interpretation of KUVP 27821 as representing Pteranodon longiceps, albeit not having a crest as large as in Geosternbergia sternbergi. KUVP 27821 is regarded to belong to a new species of this genus until more material comes to light.

\section{Dawndraco gen. nov.}

Etymology: Dawn, a sky goddess in the culture of the Iroquois, one of the Native American tribes and draco, from the Latin meaning dragon.

Type species: Dawndraco kanzai sp. nov.

Recorded temporal and stratigraphic range: Late Coniacian to early Santonian (Late Cretaceous); lower part of the Smoky Hill Chalk Member of the Niobrara Formation (Bennett 1994).

Diagnosis: As for the type and only known species.

\section{Dawndraco kanzai sp. nov.}

Pteranodon sternbergi Bennett 1992
Etymology: The specific name is based on Kanza (or Kaw), the Native American tribe from which the state name Kansas was derived.

Holotype: Partial skeleton consisting of an almost complete skull (lacking posterior region of the cranial crest and the anterior end of upper jaw) and partial mandible, almost complete vertebral column, sternum, pectoral girdle, proximal part of wings, pelvis and hind limbs housed at the Geology Museum of the University of Alberta, Edmonton, Canada (UALVP 24238, Figs. 2-4).

Occurrence: The holotype (and only known specimen) was collected in Utica, Kansas, USA.

Recorded temporal and stratigraphic range: Late Coniacian-early Santonian (Late Cretaceous); lower part of the Smoky Hill Chalk Member of the Niobrara Formation; according to Bennett (1994: Fig. 3), UALVP 24238 was found a little higher in the section than the holotype of Geosternbergia sternbergi.

Diagnosis: Rostrum anterior to the nasoantorbital fenestra more elongated than in any other pteranodontid; dorsal and ventral margins of the skull anterior to the nasoantorbital fenestra sub-parallel; posterior premaxillary process inclined for about $45^{\circ}$ relative to the ventral margin of the skull; presence of a short and blunt lacrimal process directed inside the orbit; lower temporal fenestra narrower than in other pteranodontids, with the lower portion slit-like; mandibular rami lower than in Pteranodon; articular end shorter than in Pteranodon; caudal vertebrae are longer and do not abruptly reduce in size distally as observed in Pteranodon.

Short description: The holotype of Dawndraco kanzai (UALVP 24238) is one of the most complete pteranodontid specimen known to date, consisting of the skull (lacking part of the cranial crest and the anterior end), lower jaw (lacking most of the anterior portion), vertebral column (including 10 caudal vertebrae), sternum, scapulae and coracoids, and part of the wings and hind limbs. Although the entire skeleton suffered from compression, several elements show some of their original three-dimensionality. The rostral part of the skull (anterior to the nasoantorbital fenestra) is very elongated and does not taper as observed in Pteranodon and Geosternbergia sternbergi, with dorsal and ventral margins 

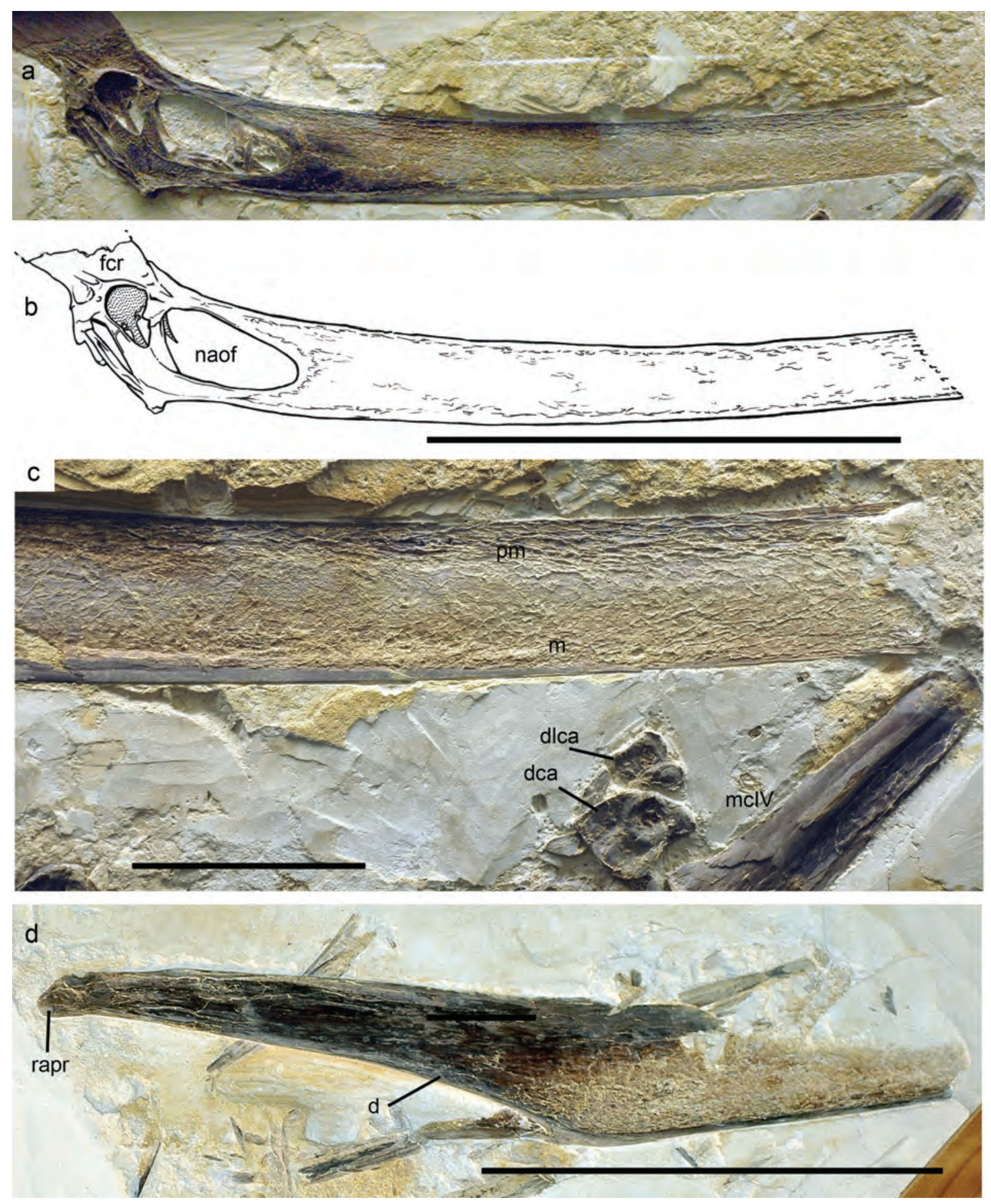

Fig. 2 - Dawndraco kanzai gen. et sp. nov., holotype (KUVP 27821). (a) photograph and (b) drawing of the complete skull; (c) detail of the preserved tip of the upper jaw; (d) lower jaw. Scale bars: a, b: $500 \mathrm{~mm}$; c: $100 \mathrm{~mm}$; d: $30 \mathrm{~mm}$. 
sub-parallel (Figs. 2a, b). For most of the lower margin the edges of the bone are very thick, indicating that it was made of denser bone and most likely having the margins of the jaws raised for part of the jaws (a pteranodontid synapomorphy, Fig. 2c). Except for the dorsal and ventral margins, the lateral side of the maxilla and premaxilla (strongly fused) was made of very delicate bone, reinforced internally by bony struts. No premaxillary crest could be identified. The lower temporal fenestra is narrower than in any other pteranodontid, particularly the lower portion. It is not sure if the depressed area in the squamosal leading to the lower temporal fenestra represents a true anatomical feature or a taphonomic artifact. The lacrimal shows a well-developed foramen lacrimale and a blunt processus lacrimalis directed inside the orbit.

As in other pteranodontids, Dawndraco shows a cranial sagittal crest formed mostly by the frontal which, however, is not complete in the holotype (Fig. 3 ). The anterior margin is covered by the posterior premaxillary process that is inclined for about $45^{\circ}$ relative to the ventral margin of the skull (more than in Pteranodon, less than in Geosternbergia). From the preserved portion, possibly the cranial crest might have been similar in size (judging from the base) and shape as the one present in Pteranodon longiceps, although with a higher angle to the horizontal plane (also more that Pteranodon sp. represented by YPM 2473). In any case, this cranial crest in Dawndraco is quite distinct from the one in Geosternbergia.

The lower jaw is incomplete and exposed lateroventally (Fig. 2d). The mandibular rami are lower and the articular end shorter than in Pteranodon (the condition of Geosternbergia is unknown). As in the upper jaw, the lateral bone of the mandibular symphysis is very thin, while the ventral margin (and likely also the dorsal margin, not preserved) is made of denser bone.

Dawndraco kanzai shows the postcranial elements fused, as expected in ontogenetically adult pterodactyloid individuals (e.g., Bennett 1993, Kellner and Tomida 2000, Kellner 2004), such as the scapula and coracoid, all elements of proximal and distal carpals (Fig. 2c), the extensor tendon process with the first wing finger phalanx and the tibia with the proximal tarsals (ankle and calcaneum). The notarium is composed of six fused dorsal vertebrae (with the first dorsal ribs fused), that form a developed supraneural plate with an oval scapular articulation surface. The pelvic bones are strongly fused to each other and with the synsacrum, which is formed by 10 or 11 vertebrae, the last one being the first caudal (Fig. 4). The remaining nine caudal vertebrae are overall longer than the ones reported for Pteranodon and do not abruptly reduce in size distally (Bennett 2001a). If the more distal caudals (not preserved) of Dawndraco also turned into a rod-like structure as in Pteranodon is unknown. Pre-pubia are also fused, forming a typical " $H$ "-shaped element, thicker than in Nyctosaurus (Fig. 4). Sternum is large and shows an elongated and low cristospine. Several sternal ribs and elements of the gastralia are preserved (see also Bennett 2001a: 64).

Remarks: According to Bennett (1994), UALVP 24238 is better regarded as Geosternbergia sternbergi (which he regarded as a species of Pteranodon). However, the differences in the rostrum are more than what is expected for individual (or geographic) variation and, in my opinion, also for sexual dimorphism, and a new genus and species (Dawndraco kanzai) is erected for this specimen. Although the crest of Dawndraco kanzai is not complete, the anterior margin clearly shows that this species lacked a high and upward-directed cranial crest. Furthermore, even taking into account the incompleteness of the holotype of Geosternbergia sternbergi, the bony portion at the base of the crest is far more developed in the latter than in Dawndraco. Likewise, the quite large rostrum with sub-parallel dorsal and ventral margins also argues against a placement of UALVP 24238 in Geosternbergia sternbergi.

\section{DISCUSSION}

The interpretation that the Pterandon-complex is taxonomically more diverse than previously supposed has implications for pterosaur studies and, therefore, a discussion about how a species of these volant archosaurs can be identified has to be addressed here. As well known, the recognition of distinct species is an old source for debate in taxonomy. There are different interpretations and approaches on how to define and diagnose a species, commonly regarded as the smallest taxonomic unit recognizable in nature. Sources of data frequently 

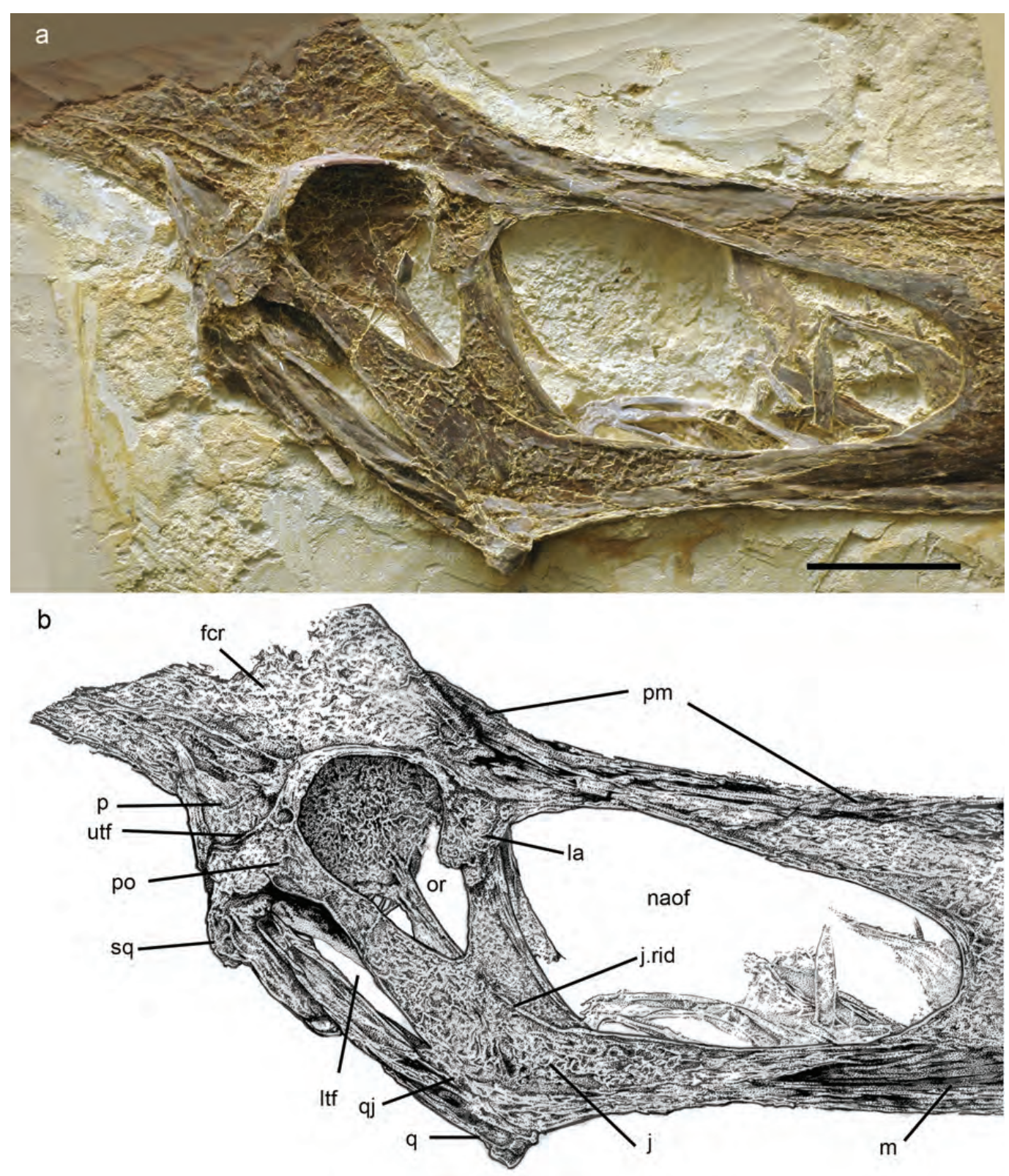

Fig. 3 - Dawndraco kanzai gen. et sp. nov., holotype (KUVP 27821), posterior region of the skull. (a) photograph and (b) drawing. Scale bar: $50 \mathrm{~mm}$.

employed to demonstrate that a particular population differs substantially from others to be ranked as a distinct species include morphology, ecology, geography, genetic information or a combination of these. When dealing with fossils, the complexity increases and time (e.g., stratigraphy) also becomes an important factor.

Still regarding fossils, identifying species is hampered mainly because of the lack of anatomical informa- tion. In the majority of cases, a paleontologist has to work with a limited number of specimens that show only the hard parts of the organism and lack soft anatomy. Even in the exceedingly rare cases when soft tissues are preserved, the amount of taxonomic information that can be extracted for taxonomic purposes is yet very limited (e.g., Kellner 1996, Tischlinger and Frey 2002, Tischlinger 2010). 


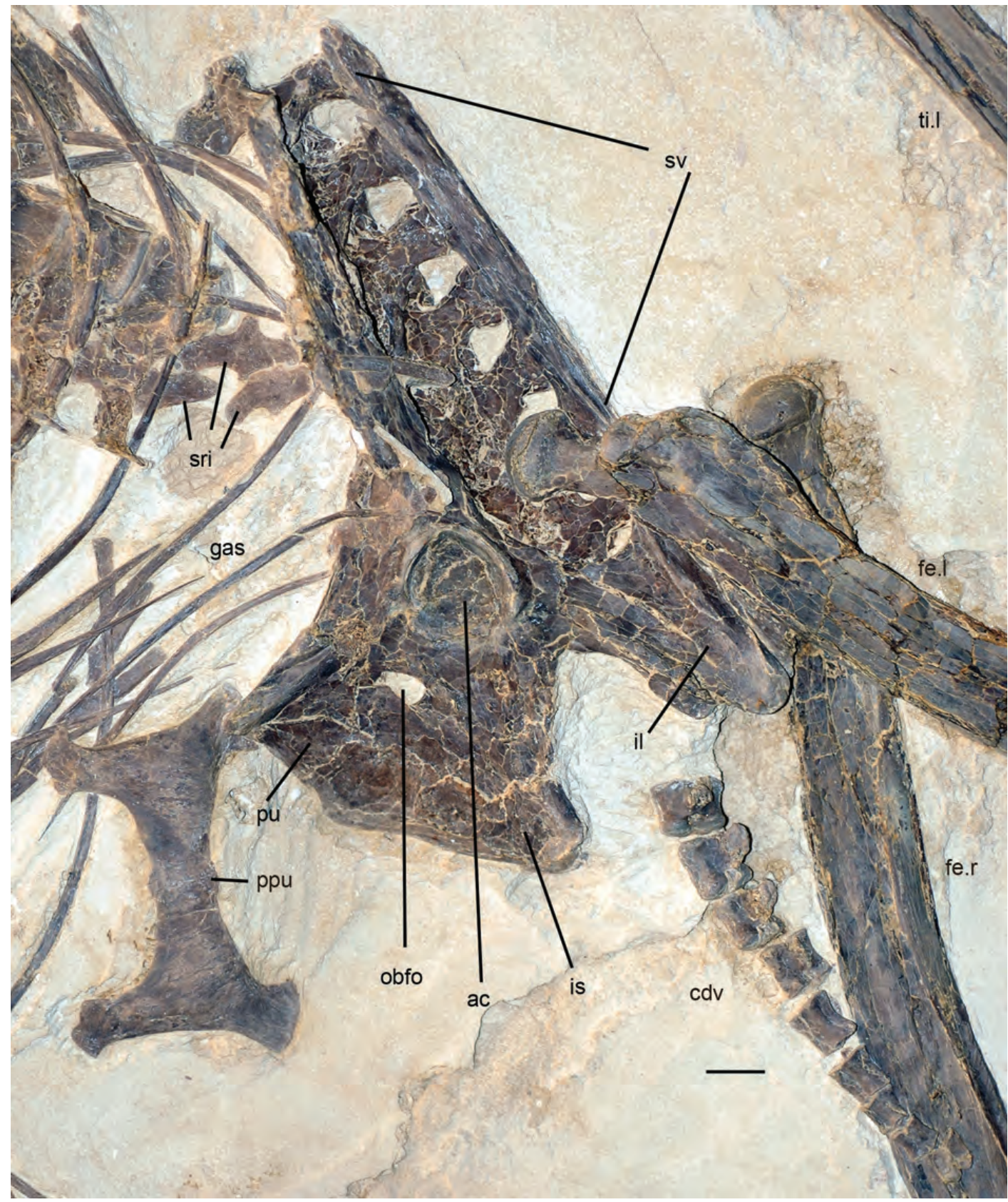

Fig. 4 - Dawndraco kanzai gen. et sp. nov., holotype (KUVP 27821) part of the skeleton showing the pelvis and the caudal vertebrae. Scale bar: $10 \mathrm{~mm}$.

The problematic involving the restricted number of individuals gets even more intricate when dealing with fossil vertebrates, since situations where there is only one specimen usually represented by a small portion of the skeleton, are prevalent. And to make taxonomic decisions even more difficult, there is the effect of taphon- omy that alters the shape and influences the perception of morphological aspects of the preserved remains.

All of the difficulties mentioned above apply to pterosaurs, to which we can add one more: the lack of modern representatives or suitable analogs. If these would exist, judging from the living forms, taxonomists 
would have at least some notion on which parts of the skeleton reveal to be useful in telling different species apart, and make use of this information regarding their extinct relatives. Although other groups also fall into the same problematic (e.g., ichthyosaurs), pterosaurs can be considered one of the extreme cases since the body of evidences emphasizing the uniqueness of these flying reptiles relative to birds and bats (most used modern analogs to answer all sorts of questions regarding those volant reptiles, e.g., Padian 1983, Habib 2008, Witton 2008), is growing. Even the few records of soft anatomy clearly show structures not found in any living animals (e.g., the pycnofibers and the composition of the wing membrane - Kellner et al. 2010). With all these differences and particularities, one should not wonder that even the phylogenetic position of the Pterosauria within reptiles is still a matter of heated debate (e.g., Padian 1983, Bennett 1996, Peters 2000, Kellner 2004), as is the problematic involving flight (e.g., Chatterjee and Templin 2004, Witton and Habib 2010) and specific feeding strategies (e.g., Kellner and Campos 2002, Humphries et al. 2007).

Species recognition in the Pterosauria (and other extinct groups) should take the following sources of data into consideration: morphology, stratigraphy and geography. Obviously the basis for taxonomic information in fossils is morphology. However, as well known, the form and structure of any portion of the skeleton can be a result of ontogeny, individual and sexual variations, and also be altered by taphonomy. Pathological features can also influence morphology, but these situations tend to be very specific and, depending on their nature, are readily detected (e.g., Kellner and Tomida 2000).

An accurate understanding of variation in shape and form of bones introduced by ontogeny can only be achieved by observing one population that presents young (preferable also hatchlings), adult and mature individuals. Unfortunately, there are very few instances where this can be claimed in the fossil record, foremost regarding pterosaurs. The sample sizes are far too small and there are hundreds of situations in which a species is only based on a scrappy and highly incomplete material (e.g., Wellnhofer 1977, Kellner and Mader 1997, Unwin and Heinrich 1999, Ibrahim et al. 2010). This is particularly true for pterosaurs, and even some rich de- posits are notorious for having only fragmented material (e.g., Kellner and Mader 1997, Unwin 2001, Costa and Kellner 2009).

The limitation of specimens is still more problematic in order to understand changes of morphology as a function of individual variation and sexual dimorphism. Recent populations show a wide spectrum of individual morphological differences that, in some cases, do reflect distinct gender. It should be noted, however, that most of the reported variations are concentrated in soft tissue anatomy, including features such as sizes and color of feathers and hair. Despite this comment, there are also variations in the skeleton (other than size) validating the perception that differences not related to taxonomy should also be expected to be found in fossil vertebrates. Again, these morphological variations in fossils in general and pterosaurs specifically, are very hard to establish due to the reduced number of specimens that can be confidently assigned to the same species. Furthermore, individual variations are generally regarded as exceptions, and therefore, one might also have to consider the odds that exactly the individual with extreme variations to be incorporated in the fossil record as opposed to the ones that show the general morphology of the species under study. Again, there is a lack of empirical data to address this interesting question properly.

Not only the comparatively low number of specimens accounts for the difficulties in establishing morphological changes as a result of ontogeny, individual variation or sexual dimorphism. The lack of stratigraphic data is also a problematic issue and has to be addressed. As generally agreed, the correct placement of specimens in the stratigraphic sequence is the only direct evidence that demonstrates if individuals with certain morphologies co-existed or if there is a significant temporal gap between them. Once more, there are several difficulties in assessing this question relative to pterosaurs. The few deposits where a considerable number of these volant reptiles have been recovered lack stratigraphic control (e.g., Kellner and Campos 1999, Fara et al. 2005, Wang and Zhou 2006). To my knowledge, the only pterosaur deposit that shows a large quantity of identifiable specimens that can be attributed to one species is the Loma del Pterodaustro in San Luis, Argentina that yielded some hundreds of the archaeopterodactyloid Ptero- 
daustro guinazui (Chiappe et al. 1998, Codorniú and Chiappe 2004). But even there, most material consists of isolated remains and fairly complete skeletons are rare. The differences reported so far in the Pterodaustro collection are mainly interpreted as ontogenetic and no study showing distinct morphologies due to individual differences or sexual dimorphism was published so far.

Based on the discussion above, caution is needed in how to interpret morphological variations, since the absence of stratigraphic control impedes to verify if certain morphs are found in the same layer or spread out in different stratigraphic levels. This problem can be exemplified with the studies of the ornithischian ceratopsian dinosaur Triceratops. Once regarded as representing over a dozen of species, some authors lumped them together (e.g., Ostrom and Wellnhofer 1986), which was followed by subsequent workers (e.g., Bennett 1994). Recently, with the finding of more specimens (the main issue for addressing this kind of questions) and a rigorous stratigraphic control (also paramount in this type of study), there is growing evidence that some of the specimens that have been regarded as individuals of different ontogenetic stages of Triceratops horridus Marsh 1889 are recovered from different stratigraphic levels and, in fact, never co-existed (Scannella 2010). Despite still at an preliminary stage, this study leads to the conclusion that at least some of the morphological changes observed in Triceratops previously regarded to reflect ontogeny or individual variations might indeed reflect taxonomic diversity.

Taphonomy also plays an essential role in morphology. In a simplified way, the shape of bones can be changed during diagenesis (or fossildiagenese) such as bone alteration with the growth of diagenetic minerals, an essentially post-burial event. Or it can be introduced during and right after the burial phase as a result of compression due to the weight of the overlying sediments depending on the depositional environment. Also, the state of decomposition of the specimen when it enters the sedimentological cycle (e.g., better preserved as opposed to partially decomposed due to necrolysis or even the activity of scavengers) might play a role in the final shape of the bones, but there are not enough empirical studies that have addressed this issue (Behrensmeyer 1978). Bones can break, which is a minor problem since, depending on the degree of the damage, original morphology can be restored. However, they can also suffer from plastic deformation that causes permanent changes in shape, which is problematic. The latter can occur when significant differences in the length of bones from left and right sides are observed (e.g., the tibiae of the holotype of Nemicolopterus crypticus, Wang, Kellner et al. 2008).

A good example where taphonomy has changed the interpretation and morphological perception can be found in the holotype of Phosphatodraco mauritanicus described by Suberbiola et al. (2003). The elongated element that in the original description was regarded as the fifth cervical vertebra is actually formed by two cervical elements, the first being the third and the second the fourth, respectively. These bones were compressed against each other, giving the false impression that they belonged to the same element that was broken in the middle region (Suberbiola et al. 2003). Although not actually changing the validity of this taxon - which is based on stratigraphy, geography and morphology (the high and peculiar neural spine of the eighth cervical vertebra), the diagnosis must be changed (which is beyond the scope of this paper) and the estimate of the wing span reduced.

Another example on how preservation can influence the perception of morphology happened with the holotype of Jidapterus edentus. In the original description (Dong et al. 2003) the dorsal margin of the skull was mistaken as the ventral (possibly due to the taphonomic compression of the bones), resulting in several misinterpretations as, for example, the elements of the posterior region of the skull and the dimension of the nasoantorbital fenestra.

From three of the main causes that can affect the morphology of fossil bones addressed here - ontogeny, individual variation and sexual dimorphism - despite the shortcomings mentioned before, variation due to ontogeny might be more readily recognizable in pterosaurs. Nowadays there is a general perception of distinct ontogenetic stages, at least for large pterodactyloids, which is mainly based on observations made by Bennett (1993) on Pteranodon specimens that have been applied to other taxa (e.g., Kellner and Tomida 2000). These observations, however, are basically restricted to the surface texture and the fusion of bones (e.g., extensor tendon 
process of the first wing phalanx, elements of the proximal and distal carpal series, scapula and coracoid).

Perhaps one case that can be used to demonstrate the change in morphology due to ontogeny is the problematic involving Sinopterus dongi and Huaxiapterus jii described by Wang and Zhou (2002) and Lü and Yuan (2005), respectively. "Huaxiapterus jii" was separated from the Sinopterus dongi mainly based on the extension of the anterior portion of the skull that includes the premaxillary crest, a typical synapomorphy of the tapejaridae (e.g., Kellner 2003) to which both species were referred (Wang and Zhou 2002, Lü and Yuan 2005). Soon after, Wang and Zhou (2006) considered "Huaxiapterus jii" synonymous with Sinopterus dongi based on the overall similarities of the skull.

Comparing both specimens, there are only two main differences: the size and the aspect of the anterior region of the skull, which is more robust in "Huaxiapterus jii". In respect of size, Sinopterus dongi is about 35\% smaller than "Huaxiapterus jii". From what is assumed regarding ontogenetic features of derived pterosaurs (Bennett 1993, Kellner and Tomida 2000), Sinopterus dongi represents a young individual showing several bones unfused that are expected to be fused in adult animals. These include the elements of the proximal and distal carpal series, the scapula and coracoid, the proximal tarsal bones and the tibia, and the extensor tendon process of the first wing finger phalanx. According to the original description (Lü and Yuan 2005), "Huaxiapterus jii" is also a young animal, showing the same unfused condition of the bones observed in Sinopterus dongi: scapula and coracoid, elements of the carpus, proximal tarsals and tibia, and the extensor tendon process of the first wing phalanx.

The second difference used to define "Huaxiapterus jii" is found in the anterior region of the skull, which is comparatively more robust in this taxon. The holotype of Sinopterus dongi shows on the anterior region of the premaxillary crest a stripe of bone (Wang and Zhou 2002: Fig. 2) suggesting that the premaxillary crest was still in process of ossifying. Therefore, it is conceivable that the skull would turn to be more robust in ontogenetially more developed individuals. Added to that, the proportions of several bones of "Huaxiapterus jii" are almost identical to those of Sinopterus dongi.
The only real shortcoming to definitively regard these taxa as synonymous is the lack of detailed stratigraphic data. The Jiufotang Formation has two distinct deposits that have yielded pterosaur fossils: the Boluochi and the Shangheshou members. The latter has furnished, among others, the primitive istiodactylid Hongshanopterus described by Wang, Campos et al. (2008), while Sinopterus dongi came from the Boluochi Member (X. Wang, personal information) in the Lamagou village, Dongdadao, Chaoyang city (Wang and Zhou 2002). Lü and Yuan (2005) only pointed out that "Huaxiapterus jii" was collected in the region of the Chaoyang city and, therefore, could have been collected in either of these deposits. Providing that both Chinese tapejarids came from the same horizon or that the time difference between these deposits is negligible, it seems safe to assume that the morphological differences of Sinopterus dongi and "Huaxiapterus jii" can be explained through ontogeny. If this interpretation is correct, during part of its growth, Sinopterus dongi would not change the proportions of several elements, but get a gradually more robust snout. Furthermore, this species does not exhibit major changes in the morphology of the crest, at least in the two growth stages represented by these specimens.

Another potential ontogenetic state of Sinopterus dongi could be represented by the holotype of Sinopterus gui, described by Li et al. (2003). According to the original description, the specimen comes from the Jiufotang Formation (no more detailed data is provided) and was collected in the region of the Chaoyang city. Among the diagnostic features, Li et al. (2003) pointed out the presence of a notarium and distinct proportion of the femur relative to the tibia. The examination of the holotype shows that it represents a very young individual (about $0.63-0.65 \%$ the size of Sinopterus dongi) and, contrary to the original description, lacks a notarium. Although details of the carpus and other portions of the skeleton are difficult to be obtained due to extensive compression and breakage, the fibula is not fused to the tibia, which is also a feature found in very young pterodactyloid individuals. The size of the femur is larger than reported (left femur $42.1 \mathrm{~mm}$ instead of $32.3 \mathrm{~mm}$ ), which makes the proportion of the femur relative to the tibia in this taxon (fe/ti: 0.64-0.67) closer to the condition observed in Sinopterus dongi (fe/ti: 0.68-0.71). The dorsal and 
left lateral surfaces of the skull were broken during the splitting of the slab and the general outline might not reflect the true cranial morphology. Although tempting, it is not conclusive to consider the holotype of Sinopterus gui a very young individual of Sinopterus dongi, since there is at least one more tapejarid species in the Jiufotang Formation: Sinopterus corollatus (Lü et al. 2008). Therefore, potentially, Sinopterus gui could also be regarded as a young individual of the latter instead (with the assumption that all came from the same deposits or that the time interval between these is small). Until more information about the tapejarids from the Jiufotang Formation become available (preferable including more stratigraphic details) this question (that includes the taxonomic status of Sinopterus gui) remains unsolved.

Regarding the Pteranodon-complex, there were a total of 14 species described, three of which are presently referred to Nyctosaurus, regarded by most authors as belonging to a distinct clade (see below). From the 11 species attributed to Pteranodon, reviewers agree that this number is inflated and might not reflect true diversity based on the available evidences, but disagree on how many species can be recognized. Miller (1972a) accepted five species classified into three sub-genera (here excluding Nyctosaurus, which he also regarded as a sub-genus of Pteranodon). Wellnhofer (1978) recognized seven species, all part of the genus Pteranodon, and disregarded the sub-genera proposed by Miller (1972a). The last reviewer was Bennett (1991, 1994), who recognized only two species (Pteranodon longiceps and Pteranodon sternbergi), both being sexually dimorphic.

Bennett's work was remarkably since he was the first to try to establish the exact stratigraphic level from which Pteranodon specimens came from. However, the stratigraphic data from older collected specimens were not recorded properly, which unfortunately is a general problem regarding pterosaur material (and other fossils as well). Nevertheless, he was able to establish the stratigraphic position of several important skulls (Bennett 1994: Fig. 3).

In terms of morphology, the two distinct species recognized by him were Pteranodon longiceps and Pteranodon sternbergi found in the higher and lower section of the Smoky Hill Chalk. Although I agree with this distinction, several morphological differences indicate that these species are not congeneric and, therefore, the genus Geosternbergia, introduced as a subgenus of Pteranodon by Miller (1972a, 1978) is reestablished. The most conspicuous differences are the shape and extension of the frontal crest, which is elongated and directed posteriorly in Pteranodon, and much larger and directed upward with a bulbous profile in Geosternbergia. The premaxillary process reaches the region above the orbit in Pteranodon, while in Geosternbergia this bone does end before (Geosternbergia sternbergi) or at (Geosternbergia maiseyi) the region corresponding to the anterior margin of the skull. The angle of this process relative the ventral margin of the skull also differs from $25-30^{\circ}$ to $40^{\circ}$ in Pteranodon and Geosternbergia, respectively. Furthermore, the lower temporal opening in Geosternbergia is larger and more oval than in Pteranodon.

Within Geosternbergia, I do recognize two species - Geosternbergia sternbergi and Geosternbergia maiseyi that differ in the extension of the frontal crest, the inclination of the posterior extension of the premaxillary, and the straight dorsal margin of the preserved portion of the nasoantorbital fenestra, which appears to be proportionally larger in the latter than in any other pteranodontid. Furthermore, the holotype of Geosternbergia maiseyi comes from the Sharon Springs Formation of the Pierre Shale Group (Bennett 1994, Martin et al. 2007), which is much higher in the stratigraphic section. Bennett (1994) has regarded KUVP 27821 (here designated as the type specimen for Geosternbergia maiseyi) as representing Pteranodon longiceps, but the morphological differences suggest that this material belongs to a distinct species closely related to Geosternbergia sternbergi. One could argue that the morphological differences of Geosternbergia maiseyi might be due to ontogeny, individual variation or even sexual dimorphism, but there is a considerable time gap between these species that never co-existed.

I do also recognize a different taxon in the material referred to Pteranodon (here named Dawndraco kanzai gen. et sp. nov.), which is based on UALVP 24238 previously regarded as a female of Geosternbergia sternbergi (Bennett 1991, 1994). Regarding stratig- 
raphy, UALVP 24238 and the type specimen of Geosternbergia sternbergi (FHSM VP 339) came from different layers of the lower part of the Smoky Hill Chalk Member of the Niobrara Formation (Bennett 1994: Fig. 3), which implies that the time gap between these specimens is comparatively not very large. However, the cranial morphology of UALVP 24238 is very distinctive from Geosternbergia and Pteranodon, starting with the extremely elongated rostrum, longer than in any pteranodontid skull known to me. This can be best shown by a new index, the rostral value $(\mathrm{RV}=$ ros-1/aenh), here defined as the rostral length (ros-1) divided by the height of the anteriormost point of the external naris or nasoantorbital fenestra (aen-h). The ros-l is measured from the anteriormost point of the external naris to the tip of the premaxillae and aen-h is measured perpendicularly from the ventral margin of the skull. While in the holotype of Pteranodon longiceps RV is 16.3, in Dawndraco it must be well over 20. Although RV cannot be confidently determined for Geosternbergia sternbergi, the preserved elements indicate that the jaw tips were elongated but not to the same degree as in Dawndraco, whose dorsal and ventral margins are still essentially parallel at the broken preserved end. Although the end tip of the snout of Dawndraco is unknown, the ending must have been more abrupt than in Pteranodon and Geosternbergia (that gradually tapers distally to points) or the jaws were exceptionally long.

Even incomplete, the preserved portion of the frontal crest in Dawndraco indicates that this structure was extended posteriorly (being in this respect more similar to Pteranodon longiceps) and not directed upward as in Geosternbergia. Regarding the lower jaw, although not complete in Dawndraco, judging from the extremely elongated rostrum, it must also have been very long, more than in other pteranodontids. Alternatively, if the lower jaw in this taxon would not followed the pattern of Pteranodon longiceps (e.g., was shorter than suspected here), this would imply a great difference between the lengths of the jaws (more than in any other pterosaur), which is an unlike condition. Lastly, the pelvis of this specimen is compressed laterally and no measurement of the pelvic canal is possible (Fig. 4).

The new interpretation of a larger taxonomic diversity in the material previously restricted to two species of Pteranodon does not necessarily invalidate some ideas presented before, such as the hypothesis of sexual dimorphism. Bennett (1992) regarded Pteranodon to show sexual dimorphism based on the presence of two types of pelves, differing mainly by the reconstructed size of the pelvic canal, which was associated with differences in wing span, size and shape of the cranial crest. In this respect, the presence of cranial crests continues to be a valid taxonomic feature for Pteranodon and other pterosaurs (see also Wang et al. 2010), but its expression (shape and size) might differ within the genders. Although the idea is tempting, it is still necessary to find specimens with the skull and pelvis showing the morphological attributes of the respective gender. A larger diversity within the Pteranodon material does not per se invalidate the hypothesis of sexual dimorphism, but makes it more difficult to select characters (and specimens) that reflect a particular gender.

Other hypotheses are more complicated to prove with the new taxonomic arrangement proposed here. The main one is the anagenetic evolving lineage hypothesized by Bennett (1994), with "Pteranodon" sternbergi evolving to Pteranodon longiceps.

The phylogenetic relationship of Pteranodon (and the Pteranodontidae, now including Dawndraco and Geosternbergia) is still a matter of debate with some authors regarding this North American pterodactyloid as being closely related to Nyctosaurus (e.g., Unwin 2003), while others consider the latter as representing a distinctive clade - the Nyctosauridae (e.g., Bennett 1994, Kellner 2003, Frey et al. 2006, Andres and Ji 2008, Wang et al. 2009). Although a revision of the Nyctosauridae is beyond the scope of the present paper, the discovery of Muzquizopteryx contributes to show the validity of this clade (Frey et al. 2006), which can be defined as the most recent common ancestor of Nyctosaurus gracilis and Muzquizopteryx coahuilensis, and all its descendants. The synapomorphies shared by members of this clade include the particular hatched-shaped deltopectoral crest of the humerus and a pteroid with a broad proximal articulation whose proximal margin is oriented perpendicular to the shaft. Among the synapomorphies of the Pteranodontidae is the extensive frontal crest, absent in the Nyctosauridae. Although some new material with an odd branching crest was recently referred 
to Nyctosaurus (but more likely to belong to a different nyctosaurid taxon), the shape and extension of this crest is quite distinct from the one reported for pteranodontids (Bennett 2003). The only other pterosaur that also exhibits a large frontal crest is Ludodactylus sibbicki. This cranial structure in this toothed flying reptile was misinterpreted in the original description as formed mainly by the parietals (Frey et al. 2003), and does not show the same extension as in the Pteranodontidae.

\section{CONCLUSION}

Some specimens previously referred to the genus Pteranodon are re-evaluated, and based on their cranial morphology the following taxa are recognized: Pteranodon longiceps, Geosternbergia sternbergi, Geosternbergia maiseyi sp. nov., and Dawndraco kanzai gen. et sp. nov. They differ mainly by features of the skull such as the direction and extension of the frontal crest, the posterior process of the premaxilla, the shape and extension of the lower temporal fenestra, and the length of the rostrum.

Although recognizing fossil species is a difficult task, particularly regarding pterosaurs, paleontologists must take into account morphology, in conjunction with stratigraphic and geographic data. Based on the present knowledge, establishing morphological variations as a function of ontogeny, individual variation and sexual dimorphism in pterosaurs is hampered by the general lack of detailed stratigraphic data on the vast majority of specimens and the limited number of fossils that can be confidently assigned to the same species. Although the present study has not eliminated the possibility to recognize such differences, caution is needed before models are generalized for these volant archosaurs.

\section{ACKNOWLEDGMENTS}

I would like to thank Alexander Averianov (Russian Academy of Sciences, St. Petersburg) and Tracy Ford (Poway, California) for pointing out important references to this project and Andre E. P. Pinheiro (Instituto de Geociências, Universidade Federal do Rio de Janeiro) for the drawings of Dawndraco kanzai that illustrate this paper. I have benefited from several discussions with colleagues, particularly Chris Bennett (Fort Hays State University, Hays, Kansas), Peter Wellnhofer
(Munich), Xiaolin Wang (Institute of Vertebrate Paleontology and Paleoanthropology, Beijing), David Peters (St. Charles, Missouri), Wann Langston (Texas Memorial Museum, The University of Texas at Austin, Austin), Kevin Padian (University of California, Berkeley), and David Unwin (University of Leicester, England). Diogenes de Almeida Campos (Museu de Ciências da Terra, Rio de Janeiro) and Douglas Riff Gonçalves (Universidade Federal de Uberlândia, Minas Gerais) are thanked for comments on earlier versions of this ms. I am also grateful to Philip Currie and Michael Caldwell (University of Alberta, Edmonton) and Baadi Bouya (Centre Minier de Khouribga, Morocco) for allowing me to examine the specimen UALVP 24238 and the holotype of Phosphatodraco mauritanicus, respectively. I am also indebted to Marilyn Fox (Peabody Museum of Natural History of the Yale University, Connecticut) for providing casts of YPM 1177 (holotype of Pteranodon longiceps) and YPM 2473.

Lastly I would like to also express my gratitude to John Graham Maisey (American Museum of Natural History, New York) for all his help and incentive while I was working on my Ph.D. at the AMNH between 19911996.

This study was partially funded by the Fundação Carlos Chagas Filho de Amparo à Pesquisa do Estado do Rio de Janeiro (FAPERJ no. E-26/102.779/2008) and the Conselho Nacional de Desenvolvimento Científico e Tecnológico (CNPq no. 307276/2009-0).

\section{RESUMO}

Considerado um dos répteis voadores melhor conhecidos, Pteranodon foi objeto de várias revisões no século passado. Encontrado exclusivamente na Formação Niobrara e no Grupo Pierre Shale (ambas do Cretáceo Superior) 11 espécies foram atribuídas a este gênero (além das três presentemente classificadas em Nyctosaurus). Apesar da concordância entre os revisores que este número está inflado, existe discordância de quantas espécies podem ser reconhecidas. A última revisão limitou a existência de apenas duas espécies (Pteranodon longiceps and Pteranodon sternbergi), ambas exibindo dimorfismo sexual. Tomando como base diversas características observadas no crânio, alguns exemplares anteriormente referidos ao gênero Pteranodon foram re-avaliados e levaram à conclusão da existência das seguintes espécies, duas novas e descritas aqui: 
Pteranodon longiceps, Geosternbergia sternbergi, Geosternbergia maiseyi sp. nov. e Dawndraco kanzai gen. et sp. nov. Estas se diferenciam por feições tais como a extensão e direção da crista formada pelo frontal, da inclinação e extensão do processo posterior das pré-maxilas, da forma e tamanho da fenestra temporal inferior e da proporção do rostro. Também é discutido nesse trabalho o procedimento de como se reconhece uma espécie de pterossauro, que deve levar em conta principalmente dados morfológicos, acompanhados de informações estratigráficas e geográficas. Existe a consciência geral de que a morfologia pode variar sem que necessariamente estas mudanças estejam ligadas a questões taxonômicas. No entanto, a ausência de dados estratigráficos detalhados, aliada ao número limitado de exemplares que possam ser consideradas com um bom nível de segurança como pertencentes a uma determinada espécie, dificulta sobremaneira o nosso entendimento de como a morfologia pode variar em função de ontogenia, variações individuais e dimorfismo sexual. Apesar do presente estudo não eliminar a possibilidade de reconhecer estas variações, cuidado deve ser empregado antes que modelos sejam generalizados para os pterossauros.

Palavras-chave: Pterosauria, Pteranodon, Dawndraco, Cretáceo Superior, Taxonomia.

\section{REFERENCES}

AVErianov AO. 2006. Evolution and Palaeobiology of Pterosaurs, Ed. by E. Buffetaut and J.-M. Mazin. Geol Soc Spec Publ, No. 217, 1-347 (2003). Paleont Jour 40: 224-225.

Andres B And Ji Q. 2008. A new pterosaur from the Liaoning Province of China, the phylogeny of the pterodactyloidea, and convergence in their cervical vertebrae. Palaeontology 51: 453-469.

BeHrensmeyer AK. 1978. Taphonomic and ecologic information from bone weathering. Paleobiology 4: 150-162.

BennetT SC. 1989. A pteranodontid pterosaur from the early Cretaceous of Peru, with comments on the relationships of Cretaceous pterosaurs. J Paleontol 63(5): 669677.

BennetT SC. 1991. Morphology of the Late Cretaceous pterosaur Pteranodon and systematics of the Pterodactyoidea. Ph. D. dissertation, University of Kansas XVII: 680. (Available from University Microfilms, Ann Arbor).

BenNetT SC. 1992. Sexual dimorphism of Pteranodon and other pterosaurs, with comments on cranial crests. Jour Vert Paleont 12(4): 422-434.
BEnNetT SC. 1993. The ontogeny of Pteranodon and other pterosaurs. Paleobiology 19: 92-106.

BenNetT SC. 1994. Taxonomy and systematics of the Late Cretaceous pterosaur Pteranodon (Pterosauria, Pterodactyloidea). Occ Pap Nat Hist Mus 169: 1-70.

BennetT SC. 1996. The phylogenetic position of the Pterosauria within the Archosauromorpha. Zool Jour Linnean Soc 118: 261-308.

BEnNetT SC. 2001a. The osteology and functional morphology of the Late Cretaceous pterosaur Pteranodon. Palaeontographica Abt A 260: 1-112.

BennetT SC. 2001b. The osteology and functional morphology of the Late Cretaceous pterosaur Pteranodon. Part II. Size and functional morphology. Palaeontographica A 260: 113-153.

BennetT SC. 2003. New crested specimens of the Late Cretaceous pterosaur Nyctosaurus. Pal Zeit 77: 61-75.

Chatterjee S And Templin RJ. 2004. Posture, locomotion, and Paleoecology of pterosaurs. Spec pap, Geol Soc Am 376: 1-64.

ChIAPPE LM ET AL. 1998. Biotic association and palaeoenvironmental reconstruction of the "Loma del Pterodaustro" fossil site (Early Cretaceous, Argentina). Geobios 31: 349-369.

Codorniú L AND CHIAPpe LM. 2004. Early juvenile pterosaurs (pterodactyloidea: Pterodaustro guinazui) from the Lower Cretaceous of central Argentina. Can J Earth Sci 41: 9-18.

Costa F And Kellner AWA. 2009. On two pterosaur humeri from the Tendaguru beds (Upper Jurassic, Tanzania). An Acad Bras Cienc 81: 813-818.

Dong ZM, SUN YW AND WU SY. 2003. On a new pterosaur from the Lower Cretaceous of Chaoyang Basin, western Liaoning. Global Geol 22: 1-7.

EAton GF. 1903. The characters of Pteranodon. Am J Sci Serie 4 16: $82-86$

EAton GF. 1910. Osteology of Pteranodon. Memoirs of the Connecticut Academy of Arts and Sciencies 2: 1-38.

FAra E, SARAiva AAF, CAmpos DA, Moreira JKR, Siebra DC AND Kellner AWA. 2005. Controlled excavations in the Romualdo Member of the Santana Formation (Early Cretaceous, Araripe Basin, northeastern Brazil): stratigraphic, palaeoenvironmental and palaeoecological implications. Palaeogeogr Palaeoclimatol Palaeoecol 218: 145-160.

Frey E, Buchy MC, Stinnesbeck W, GonzÁlez AG And Stefano A. 2006. Muzquizopteryx coahuilensis 
n.g., sp. nov., a nyctosaurid pterosaur with soft tissue preservation from the Coniacian (Late Cretaceous) of northeast Mexico (Coahuila). Oryctos 6: 19-39.

Frey E, Martill DM And Buchy MC. 2003. A new crested ornithocheirid from the Lower Cretaceous of northeastern Brazil and the unusual death of an unusual pterosaur. In: BUfFETAUT E AND MAZIN JM (Eds), Evolution and Palaeobiology of Pterosaurs. Geol Soc, London, Special Publication 217: 55-63.

Frey E AND Tischlinger H. 2000. Weichteilanatomie der Flugsaurierfüsse und Bau der Scheitelkämme: Neue Pterosaurierfunde aus den Solnhofener Schichten (Bayern) un der Crato-Formation (Brasilien). Achaeopteryx 18: $1-16$.

HАBIв MB. 2008. Comparative evidence for quadrupedal launch in pterosaurs. Zitteliana 28: 159-166.

Hargrave JE. 2007. Pteranodon (Reptilia: Pterosauria): Stratigraphic distribution and taphonomy in the lower Pierre Schale Group (Campanian), western South Dakota and eastern Wyoming. In: MARTIN JE AND PARRIS DC (Eds), The Geology and Paleontology of the Late Cretaceous Marine Deposits of the Dakotas, Geol Soc Am Spec Pap 427: 215-225.

HARKSEN JC. 1966. Pteranodon sternbergi, a new pterodactyl from the Niobrara Cretaceous of Kansas. Proc S Dakota Acad Sci 45: 74-77.

Howse SCB, Milner AR And Martill DM. 2001. Pterosaurs. In: MARTILl DM AND NAISH D (Eds), Dinosaurs of the Isle of Wight. Pal Ass, London, p. 324-355.

HUMPHRIES S, BONSER RHC, WiTTON MP AND MARTILL DM. 2007. Did pterosaurs feed by skimming? Physical modeling and anatomical evaluation of an unusual feeding method. Plos Biol 5: e204.

doi:10.1371/journal.pbio.0050204.

IBRAHIM N, UNWIN DM, MARTILl DM, BAIDDER L AND Zouhri S. 2010. A New Pterosaur (Pterodactyloidea: Azhdarchidae) from the Upper Cretaceous of Morocco. PLoS ONE 5(5): e10875. doi:10.1371/journal.pone.0010875

KELLNER AWA. 1996. Reinterpretation of a remarkably well preserved pterosaur soft tissue from the Early Cretaceous of Brazil. Jour Vert Paleont 16(4): 718-722.

Kellner AWA. 2003. Pterosaur phylogeny and comments on the evolutionary history of the group. In: BUfFETAUT E AND MAZIN J-M (Eds), Evolution and Palaeobiology of Pterosaurs. Geol Soc, London, Special Publications 217: 105-137.
KELLNER AWA. 2004. The ankle structure of two pterodactyloid pterosaurs from the Santana Formation (Lower Cretaceous), Brazil. Bulletin American Museum of Natural History 285: 25-35.

Kellner AWA and Campos DA. 1999. Vertebrate Paleontology in Brazil - a review. Episodes 22(3): 238-251.

Kellner AWA AND CAmpos DA. 2002. The function of the cranial crest and jaws of a unique pterosaur from the Early Cretaceous of Brazil. Science 297: 389-392.

Kellner AWA And Mader BJ. 1997. Archosaur teeth from the Cretaceous of Morocco. J Paleontol 71: 525527

Kellner AWA AND Tomida Y. 2000. Description of a new species of Anhangueridae (Pterodactyloidea) with comments on the pterosaur fauna from the Santana Formation (Aptian-Albian), northeastern Brazil. National Science Museum Monographs 17: 1-135.

Kellner AWA, Wang X, Tischlinger H, CAmpos DA, Hone DWE AND Meng X. 2010. The soft tissue of Jeholopterus (Pterosauria, Anurognathidae, Batrachognathinae) and the structure of the pterosaur wing membrane. Proc Royal Soc B 277: 321-329.

LI JJ, LÜ J AND ZHANG BK. 2003. A new Lower Cretaceous sinopterid pterosaur from the western Liaoning, China. Acta Geol Sin 42: 442-447 (in Chinese with an English abstract)

LÜ J AND JI Q. 2006. Preliminary results of a phylogenetic analysis of the pterosaurs from western Liaoning and surrounding areas. J Paleont Soc Korea 22: 239-261.

LÜ J, Unwin D, XU L ANd Zhang Z. 2008. A new azhdarchoid pterosaur from the Lower Cretaceous of China and its implication for pterosaur phylogeny and evolution. Naturwissenschaften 95: 891-897.

LÜ J AND YUAN O. 2005. New tapejarid pterosaur from western Liaoning, China. Acta Geol Sin 79: 453-458.

MARSH OC. 1876a. Notice of a new sub-order of Pterosauria. Am J Sci Series 3 11: 507-509.

MARSH OC. 1876b. Principal characters of American pterodactyls. Am J Sci Series 3 12: 479-480.

MARSH OC. 1884. Principal characters of Cretaceous pterodactyls. Part I. The skull of Pteranodon. Am J Sci Series 3 27: 423-426.

Martin, JE, Bertog JL AND PARRIs DC. 2007. Revised lithostratigraphy of the lower Pierre Shale Group (Campanian) of central South Dakota, including newly designated members. In: MARTIN JE AND PARRIS DC (Eds), The Geology and Paleontology of the Late Cretaceous 
Marine Deposits of the Dakotas. Geol Soc Am Spec Pap 427: 9-21.

Miller HW. 1972a. The taxonomy of the Pteranodon species from Kansas. Trans Kansas Acad Sci 74(1): 1-19.

Miller HW. 1972b. A skull of Pteranodon (Longicepia) longiceps Marsh associated with wing and body bones. Trans Kansas Acad Sci 74(1): 20-33.

Miller HW. 1973. Longicepia Miller (1972) Preoccupied by Pteranodon Marsh. Trans Kansas Acad Sci 75(1): 100.

Miller HW. 1978. Geosternbergia, a new name for Sternbergia Miller, 1972: Non Paulo (sic) Couto 1970; non Jordan, 1925. J Paleontol 52: 194.

Ostrom JH And Wellnhofer P. 1986. The Munich specimen of Triceratops with a revision of the genus. Zitteliana 14: 111-158.

PADIAN K. 1983. A functional analysis of flying reptiles and walking in pterosaurs. Paleobiol 9: 218-239.

PETERS D. 2000. A reexamination of four prolacertiforms with implications for pterosaur phylogensis. Riv Italiana Paleont Strati 106: 293-336.

SCAnNElla J. 2010. Triceratops: a model organism for deciphering dinosaur heterochrony. In: SVP Program and Abstracts 2010: 158A.

ScHOCH RM. 1984. Notes on the type specimens of Pteranodon and Nyctosaurus (Pterosauria, Pteranodontidae) in the Yale Peabody Museum collections. Postilla 194: $1-23$.

SEELEY HG. 1871. Additional evidence of the structure of the head in Ornithosaurs from the Cambrige Upper Greensand; being a supplement to "The Ornithosauria". Ann Mag Nat Hist 7(37): 20-36.

Suberbiola XP, Bardet N, Jouve S, IArochène M, Bouya B AND Amaghzaz M. 2003. A new azhdarchid pterosaur from the Late Cretaceous phosphates of Morocco. In: BufFETAUT E AND MAZIN J-M (Eds), Evolution and Palaeobiology of Pterosaurs. Geol Soc, London, Special Publications 217: 79-90.

Tischlinger H. 2010. Pterosaurs of the "Solnhofen" Limestone: new discoveries and the impact of changing quarrying practices. Acta Geol Sin 31(Supp 1): 62-63.

Tischlinger H AND FrEy E. 2002. Ein Rhamphorhynchus (Pterosauria, Reptilia) mit ungewöhnlicher Flughauterhaltung aus dem Solnhofener Plattenkalk. Archaeopteryx 20: $1-20$.

UNWIN DM. 2001. An overview of the pterosaur assemblage from the Cambridge Greensand (Cretaceous) of Eastern England. Mitt Mus Nat kd Berl, Geowiss, Reihe 4: 189221.
UNWIN DM. 2003. On the phylogeny and evolutionary history of pterosaurs. In: Buffetaut E AND MAZIN J-M (Eds), Evolution and Palaeobiology of Pterosaurs. Geol Soc, London, Special Publications 217: 139-190.

UNWIN DM AND HEINRICH WD. 1999. On a pterosaur jaw from the Upper Jurassic of Tendaguru (Tanzania). Mitt Mus Natur Berlin 2: 121-134.

WANG X, CAmpos DA, Zhou Z And Kellner AWA. 2008. A primitive istiodactylid pterosaur (Pterodactyloidea) from the Jiufotang Formation (Early Cretaceous), northeast China. Zootaxa 1813: 1-18.

Wang X, Kellner AWA, Jiang S and Meng X. 2009. An unusual long-tailed pterosaur with elongated neck from western Liaoning of China. An Acad Bras Cienc 81: 793-812.

Wang X, Kellner AWA, Jiang S, Meng X and RoDRIGUES T. 2010. New long-tailed pterosaurs (Wukongopteridae) from western Liaoning, China. An Acad Bras Cienc 82: 1045-1062.

Wang X, Kellner AWA, Zhou Z and Campos DA. 2005. Pterosaur diversity and faunal turnover in Cretaceous terrestrial ecosystems in China. Nature 437: 875879.

Wang X, Kellner AWA, Zhou Z And CAmpos DA. 2008. Discovery of a rare arboreal forest-dwelling flying reptile (Pterosauria, Pterodactyloidea) from China. Proc Natl Acad Sci 105(6): 1983-1987.

WANG X AND ZHOU ZH. 2002. A new pterosaur (Pterodactyloidea, Tapejaridae) from the Early Cretaceous Jiufotang Formation of western Liaoning, China and its implication for biostratigraphy. Chinese Sci Bull 47: 1521-1527. (English translation Chinese Science Bulletin 48: 16-23, 2003).

WANG X AND ZHOU ZH. 2006. Pterosaur assemblages of the Jehol Biota and their implication for the Early Cretaceous pterosaur radiation. Geol J 41: 405-418.

Wellnhofer P. 1977. Araripedactylus dehmi nov. gen., nov. sp., ein neuer Flugsaurier aus der Unterkreide von Brasilien. Mitt Bayer Staatsslg Paläont Hist Geol 17: 157-167.

Wellnhofer P. 1978. Pterosauria. Handbuch der Palaeoherpetologie, Teil 19. Stuttgart: Gustav Fischer Verlag, Stuttgart, $82 \mathrm{p}$.

Williston SW. 1892. Kansas Pterodactyls. Part I. Kansas University Quarterly 1: 1-13.

Williston SW. 1893. Kansas Pterodactyls. Part II. Kansas University Quarterly 2: 79-81. 
WiLListon SW. 1903. On the osteology of Nyctosaurus (Nyctodactylus), with notes on American pterosaurs. Field Columbian Museum Public, Geol Ser 2(3): 125-163.

Williston SW. 1897. Restoration of Ornithostoma (Pteranodon). Kansas University Quarterly 6: 35-51.
WitTon MP. 2008. A new approach to determining pterosaur body mass and its implications for pterosaur flight. Zitteliana 28: $143-158$

Witton MP AND HaBiB. 2010. The volancy, or not, of giant pterosaurs. Acta Geol Sin 31(Supp 1): 76-78. 